\section{Criação de Um Registro Nacional de Tumores Adrenais}

$\mathbf{M}^{\mathrm{n}}$ INHA PRIMEIRA INTENÇÃO ao esboçar um editorial para essa Edição Especial era totalmente outra. Tanto que o título da matéria seria: "Porque a Adrenal é a Mais Atraente, Sedutora e Assustadora Glândula da Endocrinologia para os Especialistas (Imaginem para os Outros!)”. Ainda escrevo sobre isto algum dia, mas neste momento optei por um assunto mais sério. As doenças que acometem as glândulas adrenais são muitas e praticamente todas raras. Entre as mais comuns, a hiperplasia adrenal congênita por deficiência de 21-hidroxilase, a doença de Addison, e a síndrome de Cushing, nem sequer se aproximam em freqüência do diabetes mellitus, da tiroidite de Hashimoto, da doença de Graves, ou da síndrome dos ovários policísticos, para ficarmos em algumas poucas.

Não se trata aqui de comparações inconseqüentes entre freqüência ou prevalência de doenças ou sub-especialidades endócrinas. Muito mais promissor e apropriado, volto-me para um tema que merece grande consideração, mas que tem sido apenas superficialmente discutido nos bastidores da nossa Sociedade. A observação que faço neste editorial tem enfoque na patologia adrenal e, mais especificamente, no carcinoma adrenal, mas na verdade vale para toda e qualquer doença que tenha baixa prevalência e que seja, assim, considerada rara ou incomum.

Embora um único caso seja suficiente para se contar toda uma história sobre determinada doença, é necessário, neste caso, que o investigador seja um ótimo observador, tenha vasto conhecimento na área, seja arguto e, mais que tudo, tenha à sua disposição um laboratório bem aparelhado para dosagens hormonais específicas (esteróides, em particular) e para avaliação em genética molecular. Mesmo assim, estudos detalhados com um ou poucos pacientes portadores de moléstias raras e pouco exploradas, são limitados.

Daí a proposição deste editorial, um desafio para todos aqueles que trabalham e têm um gosto especial por doenças incomuns na área de adrenal, em particular pelos tumores adrenais: produzir e manter um registro nacional de pacientes e formar um consórcio para estudo do material deles obtido (plasma, soro, tecido e DNA).

A idéia e o desafio ficam aqui lançados, na expectativa de que estímulo e apoio possam ser oferecidos pela Comissão Científica da SBEM e pelos associados que tenham interesse no assunto. A gerência deste consórcio poderia, com maior propriedade, ser assumida pelo Departamento Científico da sub-especialidade (no caso, o Departamento de Adrenal e Hipertensão da SBEM). Os possíveis laboratórios interessados em determinada doença adrenal ou em aspectos da doença - e não são muitos no país os que se interessam objetivamente pela patologia adrenal -, poderiam desenvolver melhor suas habilidades específicas com os recursos de que dispõem e disponibiliza-las para os demais consorciados. Quem sabe não haveria maior possibilidade em se obter melhores recursos de instituições nacionais de apoio à pesquisa, se um grande projeto temático colaborativo com abrangência nacional não fosse apresentado com a chancela da SBEM?

\section{editorial}

\author{
Claudio E. Kater
}

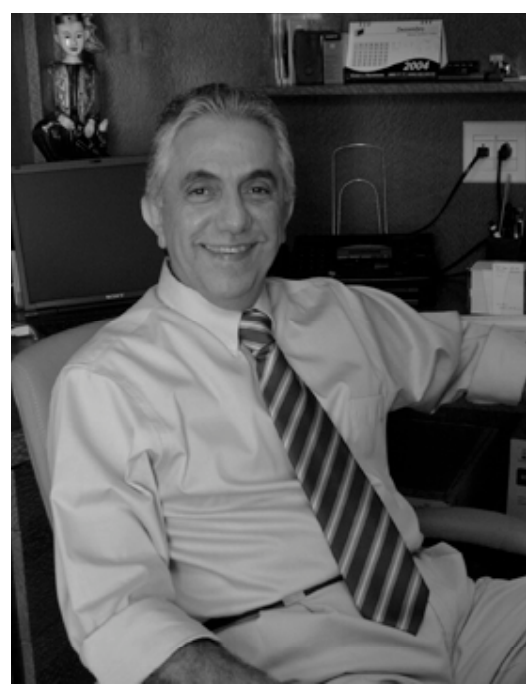

Professor Adjunto de Medicina, Disciplina de Endocrinologia, Departamento de Medicina, Universidade Federal de São Paulo (UNIFESP-EPM). Editor-chefe, $A B E \mathcal{O} M$ 
Para ficarmos em exemplos práticos, embora incipientes, nosso grupo na UNIFESP pretendeu estudar, há alguns anos atrás, uma doença adrenal pouco comum, a deficiência de $17 \alpha$-hidroxilase. Telefonamos, conversamos, fizemos anúncios e pusemo-nos a disposição de colegas para estudar seus eventuais pacientes suspeitos. No período de pouco mais de um ano, conseguimos reunir um total de 34 casos, possivelmente a maior experiência mundial isolada com esta doença. Nossos resultados, para quem se interessar, foram publicados no início de 2004 (1), mas o ponto foi que manifestamos de público nosso interesse e obtivemos a aquiescência e colaboração de colegas. Denotando o caráter colaborativo desse estudo, o trabalho foi publicado com uma lista grande de colaboradores nacionais, englobados sob a denominação "Grupo Multidisciplinar Brasileiro de Estudo da Hiperplasia Adrenal Congênita"

Mais recentemente, Ana Claudia Latronico e Berenice Mendonça convidaram colegas de vários serviços para uma reunião onde foram apresentadas e discutidas as experiências individuais acumuladas com o diagnóstico, tratamento e prognóstico de pacientes com carcinoma adrenal, doença também rara, mas, à semelhança da deficiência de $17 \alpha$-hidroxilase, possivelmente mais comum no Brasil do que em outros países, por razões ainda a serem decifradas. Os dados preliminares daquela reunião são apresentados neste número da revista (2). Ainda esta mesma edição traz outros estudos de projetos colaborativos menos ambiciosos que acredito possam ser ampliados no futuro.

Para mim, o grande exemplo neste sentido é a experiência marcante que vem sendo publicada pelo grupo italiano. Vários consórcios na Itália e alguns englobando outros países europeus, têm arregimentado um número extraordinário de pacientes portadores de condições que de outra forma seriam reportados como relatos de casos ou de pequena e inexpressiva casuística.

Por ter um elevado impacto social e pelas perspectivas de desenvolvimento de técnicas que permitam diagnóstico precoce, identificação de casos familiares, definição mais apropriada do prognóstico, etc, o estudo do carcinoma adrenal mostra-se interessante para a tentativa de um primeiro registro nacional de dados. Quero, portanto, lançar um desafio, já acompanhado de meu compromisso de adesão: provocar a atual Presidente do Departamento de Adrenal e Hipertensão da SBEM, nossa querida Margaret de Castro, a assumir nos próximos dois anos de sua gestão a responsabilidade de iniciar este registro e convocar colegas para compor este pretenso consórcio.

Vale relembrar, até como estímulo adicional, que este projeto poderia ser a continuação do que ela mesma (com a ajuda de José Antunes Rodrigues, Ayrton Moreira e outros) iniciou há 5 anos, o $1^{\text {st }}$ International Meeting on Adrenal Diseases - Basic and Clinical Aspects, excelente reunião realizada no campus da Faculdade de Medicina de Ribeirão Preto, em meados de 1999.

Gostaria, antes de terminar, de agradecer a todos os brilhantes colaboradores nacionais e estrangeiros que colaboraram nesta Edição Especial sobre Doenças Adrenais, pelo seu interesse, participação e entusiamo. Destaco, também, meu reconhecimento especial para a co-editora convidada e amiga, Berenice Mendonça, que em meio a atribulações acadêmicas, encontrou tempo e disposição para nos auxiliar no preparo esta Edição.

\section{REFERÊNCIAS}

1. Costa-Santos M, Kater CE, Auchus R, and the Brazilian Congenital Adrenal Hyperplasia Multicenter Study Group. Two prevalent CYP17 mutations and genotypephenotype correlation in 24 Brazilian patients with 17hydroxylase deficiency. J Clin Endocrinol Metab 2004;89:49-60.

2. Latronico AC, Mendonça BB. Tumores Adrenocorticais Novas Perspectivas. Arq Bras Endocrinol Metab 2004;48/5:642-646. 